\title{
Dissemination of carbapenem resistance and plasmids encoding carbapenemases in Gram-negative bacteria isolated in India
}

\author{
Prasanth Manohar ${ }^{1} \dagger$, Sebastian Leptihn (D) ${ }^{2,3}$, Bruno S. Lopes ${ }^{4}$ and Ramesh Nachimuthu ${ }^{1 *}$ \\ ${ }^{1}$ Antibiotic Resistance and Phage Therapy Laboratory, Department of Biomedical Sciences, School of Bioscience and Technology, \\ Vellore Institute of Technology (VIT), Vellore 632014, Tamil Nadu, India; ${ }^{2}$ Zhejiang University-University of Edinburgh (ZJU-UoE) \\ Institute, Zhejiang University, Haining, Zhejiang 314400, China and Department of Infectious Diseases, Sir Run Run Shaw Hospital, \\ Zhejiang University School of Medicine, Hangzhou, China; ${ }^{3}$ University of Edinburgh Medical School, Biomedical Sciences, College of \\ Medicine \& Veterinary Medicine, The University of Edinburgh, 1 George Square, Edinburgh EH8 9JZ, UK; ${ }^{4}$ School of Medicine, Medical \\ Sciences and Nutrition, Medical Microbiology, University of Aberdeen, Aberdeen AB25 2ZD, UK
}

*Corresponding author. E-mail: drpnramesh@gmail.com

†Present address: Zhejiang University-University of Edinburgh (ZJU-UoE) Institute, Zhejiang University, Haining, Zhejiang 314400 , China.

Received 10 November 2020; accepted 27 January 2021

Background: Carbapenem resistance in Gram-negative bacteria is an ongoing public health problem of global dimensions leaving very few treatment options for infected patients.

Objectives: To study the dissemination of plasmid-borne carbapenemase genes in Gram-negative bacteria from a diagnostic centre in Tamil Nadu, India.

\begin{abstract}
Methods: A total of 151 non-repetitive isolates belonging to 10 genera were collected between January 2015 and December 2016 from a diagnostic centre in Tamil Nadu. The isolates included Escherichia coli $(n=57)$, Klebsiella pneumoniae $(n=45)$, Pseudomonas aeruginosa $(n=10)$, Salmonella Typhi $(n=8)$, Enterobacter cloacae $(n=8)$, Acinetobacter baumannii $(n=7)$, Serratia marcescens $(n=5)$, Achromobacter xylosoxidans $(n=5)$, Proteus mirabilis $(n=5)$, Klebsiella oxytoca $(n=5)$ and Elizabethkingia meningoseptica $(n=1)$.

Results: Of the 151 isolates, $71 \%(n=107)$ and $68 \%(n=103)$ were found to be resistant to meropenem and imipenem, respectively. The most prevalent $\beta$-lactamase gene was bla $a_{\mathrm{NDM}-1}(n=22)$, followed by bla ${ }_{\mathrm{OXA}-181}$ $(n=21)$, bla $a_{\mathrm{GES}-1}(n=11)$, bla $a_{\mathrm{OXA}-51}(n=9)$, bla $a_{\mathrm{GES}-9}(n=8)$, bla $\mathrm{OXX}_{-23}(n=7)$ and bla $_{\mathrm{IMP}-1}(n=3)$. We also observed bla $a_{\mathrm{OXA}-23}$ in E. coli $(n=4)$, and three K. pneumoniae were positive for both, bla $a_{\mathrm{OXA}-23}$ and bla $\mathrm{OXA}-51$. Plasmid incompatibility (inc/rep) typing results showed that the resistance genes $(n=11)$ were present in the isolates carrying plasmid-types IncX, IncA/C, IncFIA-FIB and IncFIIA. The plasmid-borne resistance genes in E. coli and K. pneumoniae were transferred to susceptible E. coli AB1157.
\end{abstract}

Conclusions: This study highlights the prevalence of carbapenem resistance and the acquisition of plasmid-borne carbapenemase genes in Gram-negative bacteria isolated at this centre.

\section{Introduction}

Antibiotic resistance is an emerging global health problem due to the injudicious use of antibiotics. ${ }^{1}$ It is considered as a major clinical and public health problem because of the limited treatment options available to treat infections caused by antibiotic-resistant bacteria. The increasing bacterial resistance rates to most available antibiotics, including penicillin, cephalosporins, carbapenems, and colistin pose a serious threat. ${ }^{1}$ The WHO recently listed carbapenem-resistant Acinetobacter baumannii, Pseudomonas aeruginosa and ESBL-producing Enterobacteriaceae as pathogens of critical importance. ${ }^{2}$ Gram-negative bacteria (GNB), especially Enterobacteriaceae, have developed resistance to a broadspectrum of antibiotics responsible for significant mortality around the globe. ${ }^{3}$ Carbapenems are considered as one of the last resort antibiotics against infections caused by multidrug-resistant GNB. ${ }^{4}$ The emergence of carbapenem resistance in Enterobacteriaceae is a major clinical problem, particularly for patients with complex infections, especially when they are immunocompromised or suffering from multiple diseases. ${ }^{5}$ Pathogens that are resistant to carbapenems often show high levels of resistance to other

(c) The Author(s) 2021. Published by Oxford University Press on behalf of the British Society for Antimicrobial Chemotherapy.

This is an Open Access article distributed under the terms of the Creative Commons Attribution Non-Commercial License (http://creativecom mons.org/licenses/by-nc/4.0/), which permits non-commercial re-use, distribution, and reproduction in any medium, provided the original work is properly cited. For commercial re-use, please contact journals.permissions@oup.com 
commonly used antibiotics. This not only leads to high mortality rates, but often the patient's time in the hospital is prolonged and medical expenses accumulate, placing an emotional, economic and financial burden on families, especially in resource-limited countries. ${ }^{6}$

The assessment of the worldwide rise in antibiotic resistance has become very difficult due to the increasing rates of multidrug resistance shown by pathogens and the lack of harmonized surveillance systems. ${ }^{7}$ Moreover, the coexistence of carbapenem resistance genes with other genes such as plasmid-mediated AmpC or plasmid-mediated quinolone resistance has resulted in an increased acquisition of resistance, causing community- and hospital-acquired infections. ${ }^{8,9}$ The carbapenem-hydrolysing oxacillinases (CHDL) are the major source of carbapenem resistance in A. baumannii. The first report of OXA-23-type $\beta$-lactamase in A. baumannii was in 1985 in Edinburgh, UK. ${ }^{10}$ Recently, OXA-23 was also reported in members of the Enterobacteriaceae family. ${ }^{11-14}$ The OXA-51-like $\beta$-lactamase was first reported by the same laboratory in Edinburgh from isolates collected from three hospitals in Buenos Aires, Argentina. At present, more than 150 variants of OXA-51 have been reported worldwide. ${ }^{15}$ These intrinsic enzymes (OXA-51-like) in A. baumannii are naturally chromosome-borne, but in rare cases are also reported to be encoded on plasmids. ${ }^{16}$ Previously, we reported the distribution of colistin resistance in the study region, and investigated the importance of integrons in disseminating antibiotic resistance. ${ }^{17,18}$ In the present study, dissemination of carbapenem resistance among Gram-negative bacteria was evaluated, and the role of plasmid transfer in developing carbapenem resistance was also explored in further detail.

\section{Materials and methods}

\section{Ethics approval}

Ethics approval was from the Institutional Ethical Committee for studies on Human subjects (IECH), ref. no. VIT/IECH/004/Jan2015.

\section{Isolate collection and classification}

During January 2015 and December 2016, a total of 151 Gram-negative bacterial isolates were collected from Hi-Tech diagnostic centre in Chennai, Tamil Nadu, India. Bacteria were isolated from urine, blood, pus, bronchial secretion, CSF, pulmonary secretion and bile fluid. The collected isolates were received at the Antibiotic Resistance and Phage Therapy Laboratory, VIT, Vellore, for further analyses. Bacterial identification was carried out using the VITEK identification system (bioMérieux) and 16S rRNA gene nucleotide sequence analysis using universal primers $27 \mathrm{~F}$ and $1492 \mathrm{R}^{18}$ DNA was extracted from all the isolates using a boiling lysis method. Briefly, overnight-grown bacterial cultures were centrifuged at $8000 \mathrm{~g}$ for $10 \mathrm{~min}$, and the bacterial pellet was resuspended in $100 \mu \mathrm{L}$ of sterile distilled water. The cells were boiled at $100^{\circ} \mathrm{C}$ for $10 \mathrm{~min}$ and the mixture was centrifuged at $2000 \mathbf{g}$ for $2 \mathrm{~min}$. The supernatant was extracted and used as a source of template for PCR. The PCR products were sequenced and identified to the species level using the BLASTN tool (https://blast.ncbi.nlm.nih.gov/Blast.cgi? PAGE_TYPE=BlastSearch).

\section{Antibiotic susceptibility testing and MICs}

Antibiotic resistance profiling was performed using the disc diffusion method according to CLSI guidelines. ${ }^{19}$ The antibiotic discs used for this study were gentamicin $(10 \mu \mathrm{g})$, co-amoxiclav $(30 \mu \mathrm{g})$, cefotaxime $(30 \mu \mathrm{g})$, ertapenem $(10 \mu \mathrm{g})$, amikacin $(30 \mu \mathrm{g})$, meropenem $(10 \mu \mathrm{g})$, colistin $(10 \mu \mathrm{g})$ and cefepime $(30 \mu \mathrm{g})$. Briefly, on the Muller-Hinton (MH) agar plate, a lawn culture of bacteria was prepared by adjusting the bacterial culture to 0.5 McFarland turbidity standards. The antibiotic discs were placed on the bacterial lawn and the $\mathrm{MH}$ plates were incubated at $37^{\circ} \mathrm{C}$ for $18 \mathrm{~h}$. Based on the zone of inhibition, the results were interpreted as susceptible, intermediate or resistant. MICs were determined by the broth microdilution method for meropenem and imipenem, as described previously. ${ }^{18}$ Briefly, in the 96well microtitre plate, $100 \mu \mathrm{L}$ of cation-adjusted $\mathrm{MH}$ broth was added to each well. Meropenem or imipenem was added at concentrations ranging from 0.06 to $128 \mathrm{mg} / \mathrm{L}$ in columns 1 to 11 , whereas column 12 served as growth control. The bacterial culture at $5 \times 10^{5}$ dilutions from the overnight grown cells was added and the plates were incubated at $37^{\circ} \mathrm{C}$ for $20 \mathrm{~h}$. Escherichia coli ATCC 25922 was used as a control strain and the results were interpreted according to CLSI guidelines. ${ }^{19}$

\section{Molecular analysis of resistance-related genes}

The isolates were screened for the presence of the carbapenem resistance genes bla $a_{\mathrm{NDM}}$, bla $a_{\mathrm{OXA}-48-\mathrm{like}}$ bla $a_{\mathrm{KPC}}$, bla $_{\mathrm{IMP}}$ and bla $\mathrm{VIIM}{ }^{18} \mathrm{~A}$ second multiplex PCR was also performed for bla $a_{\mathrm{DIM}}, b l a_{\mathrm{BIC}}, b a_{\mathrm{GIM}}$, bla $_{\mathrm{SIM}}$ and bla $_{\mathrm{AIM} .}{ }^{20}$ The bla $a_{\mathrm{OXA}-1}, b l a_{\mathrm{OXA}-4}, b_{\mathrm{OXA}-30}, b_{a_{\mathrm{GES}-1-9}}$ and bla $a_{\mathrm{GES}-11}$ were screened as described earlier. ${ }^{21}$ The bla OXA-23-like, $_{\text {bla }} a_{\text {OXA-24-like, }}$ bla $a_{\text {OXA-51-like }}$ and bla $a_{\text {OXA- }}$ 58-like were screened for according to Woodford et al. ${ }^{22}$ The primers and PCR conditions used for analyses are given in Tables S1 to S5 (available as Supplementary data at JAC-AMR Online). The PCR amplicons of the resistance genes were sequenced and genes were confirmed using NCBI BLASTN program (https://blast.ncbi.nlm.nih.gov/Blast.cgi?PAGE_TYPE=BlastSearch).

\section{Plasmid isolation and plasmid incompatibility grouping}

Plasmid isolation was performed for all the isolates harbouring resistance genes. The isolation of plasmid DNA was performed using HiPurA Plasmid DNA Miniprep Purification Kit (Himedia, India). Chromosomal DNA contamination was checked using the $16 \mathrm{~S}$ rRNA primers as described earlier. ${ }^{23}$ The purified plasmid DNA was used for screening $\beta$-lactamase genes. Plasmid incompatibility (inc/rep) typing (FIA, FIB, FIC, HI1, HI2, I1-Ig, L/M, N, P, W, T, $\mathrm{A} / \mathrm{C}, \mathrm{K}, \mathrm{B} / \mathrm{O}, \mathrm{X}, \mathrm{Y}, \mathrm{F}$, and FIIA replicons) was performed using multiplex $\mathrm{PCR}$ following the primers and PCR conditions as described by Carattoli et al. ${ }^{24}$ The primers and PCR conditions used for analysis are given in Table S6.

\section{Conjugation studies}

Representative carbapenem-resistant isolates harbouring plasmid-borne resistance were tested for conjugation using the broth-mating method. ${ }^{18}$ Briefly, the donor strain (strains carrying resistance genes) and the recipient strain (E. coli AB1157, Str') were grown overnight in $\mathrm{MH}$ broth at $37^{\circ} \mathrm{C}$ and mixed in 9:1 ratio each of donor and recipient. The cells were kept undisturbed for $6 \mathrm{~h}$ at $37^{\circ} \mathrm{C}$ and plated onto antibiotic-containing medium. The isolates which grew on both meropenem and streptomycin were considered as transconjugants. All the donor strains were tested for streptomycin resistance and MIC values ( $<2 \mathrm{mg} / \mathrm{L}$ ) were found to be suitable for the assay. The transconjugants were confirmed for the presence of respective carbapenem resistance genes using PCR. The list of isolates used for conjugation studies is given in Table 57 .

\section{Results}

\section{Bacterial identification}

In this cross-sectional study, a total of 151 non-duplicate, Gramnegative bacteria belonging to 10 genera were studied which included E. coli ( $n=57,37.7 \%)$, Klebsiella pneumoniae ( $n=40$, $26.4 \%)$, Klebsiella oxytoca $(n=5,3.3 \%)$, P. aeruginosa $(n=10$, $6.6 \%)$, Salmonella Typhi $(n=8,5.2 \%)$, Enterobacter cloacae $(n=8$, 
Table 1. Antibiotic susceptibility testing employing the disc diffusion method and the prevalence of MDR isolates among 151 Gram-negative bacteria isolated from clinical samples

\begin{tabular}{|c|c|c|c|c|c|c|c|c|c|}
\hline \multirow[b]{2}{*}{ Bacteria/antibiotic } & \multicolumn{8}{|c|}{ No. of resistant isolates (\%) } & \multirow[b]{2}{*}{ Total MDR isolates $(n=151)$} \\
\hline & GEN & AMC & IPM & ETP & AMK & MEM & CST & FEP & \\
\hline E. coli $(n=57)$ & $51(89)$ & $45(79)$ & $46(81)$ & $38(67)$ & $49(86)$ & $43(75)$ & $35(61)$ & $45(79)$ & $54(95)$ \\
\hline K. pneumoniae $(n=40)$ & $33(83)$ & $31(78)$ & $32(80)$ & $28(70)$ & $36(90)$ & $32(80)$ & $29(73)$ & $30(75)$ & $32(80)$ \\
\hline P. aeruginosa $(n=10)$ & $10(100)$ & $10(100)$ & $9(90)$ & $6(60)$ & $8(80)$ & $10(100)$ & $7(70)$ & $8(80)$ & $10(100)$ \\
\hline S. Typhi $(n=8)$ & $6(75)$ & $7(88)$ & $5(63)$ & $5(63)$ & $6(75)$ & $7(88)$ & $5(63)$ & $7(88)$ & $7(88)$ \\
\hline E. cloacae $(n=8)$ & $7(88)$ & $8(100)$ & $7(88)$ & $6(75)$ & $8(100)$ & $8(100)$ & $6(75)$ & $7(88)$ & $8(100)$ \\
\hline A. baumannii $(n=7)$ & $7(100)$ & $6(86)$ & $7(100)$ & $6(86)$ & $7(100)$ & $7(100)$ & $5(71)$ & $7(100)$ & $7(100)$ \\
\hline S. marcescens $(n=5)$ & $5(100)$ & $5(100)$ & $5(100)$ & $3(60)$ & $5(100)$ & $5(100)$ & $4(80)$ & $5(100)$ & $5(100)$ \\
\hline A. xylosoxidans $(n=5)$ & $5(100)$ & $5(100)$ & $4(80)$ & $2(40)$ & $5(100)$ & $5(100)$ & $4(80)$ & $5(100)$ & $5(100)$ \\
\hline K. oxytoca $(n=5)$ & $4(80)$ & $5(100)$ & $5(100)$ & $4(80)$ & $5(100)$ & $5(100)$ & $4(80)$ & $5(100)$ & $5(100)$ \\
\hline P. mirabilis $(n=5)$ & $5(100)$ & $5(100)$ & $4(80)$ & $4(80)$ & $5(100)$ & $5(100)$ & $4(80)$ & $5(100)$ & $5(100)$ \\
\hline E. meningoseptica $(n=1)$ & $1(100)$ & $1(100)$ & $1(100)$ & 0 & $1(100)$ & $1(100)$ & $1(100)$ & $1(100)$ & $1(100)$ \\
\hline
\end{tabular}

Values represent the number of resistant isolates, \% is listed in brackets. Isolates were defined as MDR only when the isolates are resistant to three or more antibiotics. Abbreviations: GEN, gentamicin; AMC, co-amoxiclav; IPM, imipenem; ETP, ertapenem; AMK, amikacin; MEM, meropenem; CST, colistin; FEP, cefepime.

5.2\%), A. baumannii $(n=7,4.6 \%)$, Serratia marcescens $(n=5$, $3.3 \%)$, Achromobacter xylosoxidans $(n=5,3.3 \%)$, Proteus mirabilis $(n=5,3.3 \%)$ and Elizabethkingia meningoseptica $(n=1,0.6 \%)$. Most of the isolates were isolated from urine (37\%; 56/151) and blood (28\%; 42/151) and from other sources such as pus (7\%), bronchial secretion (2\%), CSF (1\%), pulmonary secretion (1\%), bile fluid $(5 \%)$ or from sources that were not documented (19\%).

\section{Antibiotic susceptibility studies}

Table 1 summarizes the antibiotic susceptibility pattern of all the isolates tested against eight different antibiotics. Meropenem MICs showed that 107/151 (71\%) isolates were resistant (Figure 1), whereas $128(84.7 \%)$ isolates were meropenem-resistant when analysed by the disc diffusion method. For imipenem, 68\% $(n=103)$ were resistant by microbroth dilution method whereas $83 \%(n=125)$ were resistant according to the disc diffusion method. MIC 50 and MIC $_{90}$ values for meropenem were $4 \mathrm{mg} / \mathrm{L}$ and $16 \mathrm{mg} / \mathrm{L}$, respectively, and for imipenem the $\mathrm{MIC}_{50}$ was $4 \mathrm{mg} / \mathrm{L}$ and the $\mathrm{MIC}_{90}$ was $16 \mathrm{mg} / \mathrm{L}$.

\section{Distribution of carbapenemase resistance genes}

Of the 57 E. coli, 32 isolates carried carbapenemases (bla $a_{\mathrm{NDM}}$,

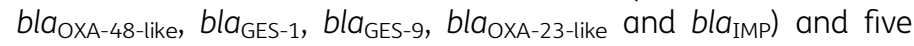
E. coli isolates carried more than one of the carbapenem resistance genes (Figure 2). Among the K. pneumoniae strains, 19/40 carried the studied genes (bla $a_{\mathrm{NDM}}$, bla $_{\mathrm{OXA}-48-\mathrm{like}}$, bla $_{\mathrm{GES}-1}$, bla $_{\mathrm{GES}-9}$, bla $_{\mathrm{OXA}-23-}$ like, $\left.b a_{\mathrm{OXA}-51-\text { like }}\right)$, and one isolate was positive for both bla $a_{\mathrm{NDM}}$ and

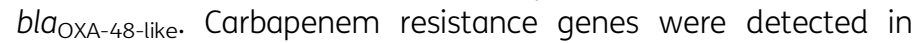
$70 / 151$ by $P C R$, and 10 isolates had more than one gene type. The most prevalent resistance genes were bla $a_{\mathrm{NDM}}(n=22)$, bla $a_{\mathrm{OXA}-48-\text { like }}$ $(n=21)$, bla $a_{\mathrm{GES}-1}(n=11)$, bla $_{\mathrm{GES}-9}(n=8)$, bla $\mathrm{OXA}_{23-\text { like }}(n=7)$, bla OXA-51-like $(n=9)$ and bla IMP $(n=3)$. None of the $\beta$-lactamase genes bla $a_{\mathrm{KPC}}, b a_{\mathrm{VIM}}, b l a_{\mathrm{BIC}}, b l a_{\mathrm{GIM}}, b a_{\mathrm{DIM}}, b l a_{\mathrm{SIM}}$ or $b l a_{\mathrm{AIM}}$ were detected in the isolates. Sequencing of genes showed that all the

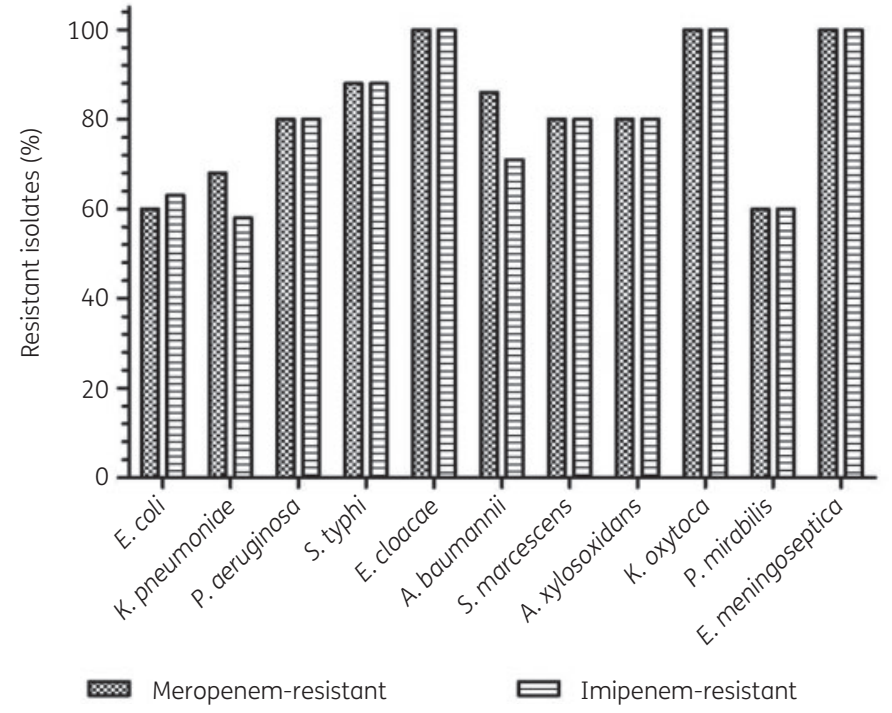

Figure 1. The distribution of Gram-negative bacteria and comparison of imipenem and meropenem resistance.

amplified $b a_{\mathrm{NDM}}$ genes were $b a_{\mathrm{NDM}-1}$, bla $a_{\mathrm{OXA}-48-\text { like }}$ genes were bla $a_{\mathrm{OXA}-181}$, and bla $a_{\mathrm{IMP}}$ genes were bla $\mathrm{I}_{\mathrm{IMP}-1}$.

\section{Plasmid incompatibility typing and conjugation}

Plasmid DNA was isolated from 70 isolates that carried resistance genes (Table 2). In total, of the 151 isolates studied, 70 isolates carried resistance genes, of which 11 were plasmid-borne and 59 were chromosomal. Of the $37 \mathrm{E}$. coli isolates, 32 isolates carried resistance genes, of which six were plasmid-encoded. Among the 40 K. pneumoniae strains, only 19 isolates carried resistance genes, of which three were encoded on plasmids. In E. cloacae, one isolate carried bla $a_{\mathrm{NDM}-1}$ on a plasmid and one $P$. mirabilis carried plasmidborne bla IMP-1. Plasmid incompatibility/replicon (inc/rep) typing 


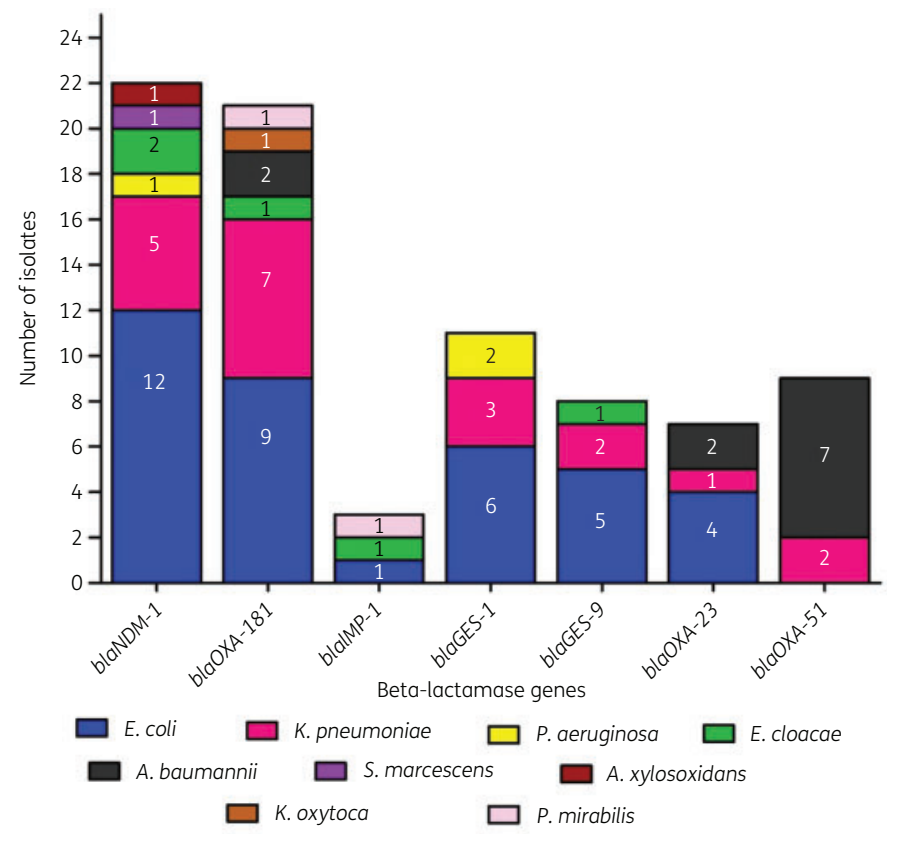

Figure 2. The distribution of carbapenemase genes among Gram-negative bacteria isolated from the clinical samples. A total of 20 resistance genes were studied that include bla $a_{\mathrm{NDM}}, b l a_{\mathrm{OXA}-48-l i k e}, b l a_{\mathrm{KPC}}, b l a_{\mathrm{IMP}}$, bla $a_{\mathrm{VIM}}, b l a_{\mathrm{DIM}}, b l a_{\mathrm{BIC}}, b l a_{\mathrm{GIM}}, b l a_{\mathrm{SIM}}, b l a_{\mathrm{AIM}}$ bla $a_{\mathrm{OXA}-1}, b l a_{\mathrm{OXA}-4}, b l a_{\mathrm{OXA}-30}$,

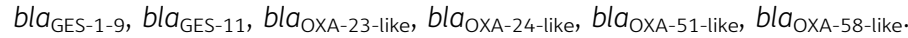
The genes bla $a_{\mathrm{KPC}}, b l a_{\mathrm{VIM}}, b l a_{\mathrm{DIM}}, b l a_{\mathrm{BIC}}, b l a_{\mathrm{GIM}}, b l a_{\mathrm{SIM}}, b l a_{\mathrm{AIM}}, b l a_{\mathrm{OXA}-1}$,

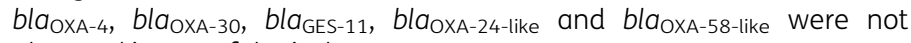
observed in any of the isolates.

results showed that the plasmids belonged to inc/rep types: IncX, IncA/C, IncFIA-FIB and IncFIIA (Table 2). E. coli isolates that carried IncX (EC10), IncA/C (EC21) and IncFIA-FIB (EC29) -type plasmids harboured bla NDM-1 $_{1}$ genes. E. coli strains carrying IncFIIA (EC39) and IncFIA-FIB (EC29) harboured bla OXA-181 genes and IncFIA-FIB (EC47) type plasmids carried bla $a_{\mathrm{GES}-1 / 9}$ genes. K. pneumoniae isolates carrying IncFIA-FIB (KP10) -type plasmids carried bla $a_{\mathrm{NDM}-1}$ genes, and InCA/C (KP31 and KP39) carried bla ${ }_{\mathrm{GES}-1}$, bla $\mathrm{OXX}_{\text {-23/51-like }}$ genes. One E. cloacae isolate with IncFIIA (EL3)-type plasmid harboured bla $a_{\mathrm{NDM}-1}$ gene and one $P$. mirabilis isolate carrying IncFIAFIB (PM5)-type plasmid had the bla IMP-1 gene.

In total, 11 carbapenem-resistant isolates harbouring plasmid-encoded resistance were subjected to conjugation studies (Table 2). The six E. coli isolates EC10, 21, 29, 39, 44, and 47 were found to facilitate the transfer of plasmid-mediated resistance to susceptible $E$. coli AB1157. Inter-generic transfer of NDM-1 was observed in one K. pneumoniae isolate (KP10) (Table 2).

\section{Discussion}

In India, carbapenem-resistant Gram-negative bacteria have been reported as becoming more frequent. ${ }^{17,18}$ In this study, the distribution of carbapenem-resistant isolates in 10 genera of Gram-negative bacteria isolated at a diagnostic centre in Tamil Nadu, India, has been investigated. Previous studies describe the increasing prevalence of ESBL and MBL producers among Gramnegative bacteria in India. ${ }^{25-28}$
In this study, experiments determining MIC values show that $107 / 151(71 \%)$ isolates were resistant to meropenem, correlating with the observation made by the disc diffusion method $(n=128)$. All the 70 isolates harbouring carbapenem resistance genes were resistant according to the results of both the methods (MIC and disc diffusion). As carbapenems are one of the last-resort antibiotics available to treat infections caused by Gram-negative bacteria, the prevalence of carbapenem resistance is of worldwide concern. Our previous studies had reported the dissemination of carbapenem-resistant bacteria and carbapenem resistance genes among Gram-negative bacteria in Tamil Nadu. ${ }^{17,18}$ Here, we report the prevalence $(71 \%)$ of carbapenem-resistant isolates among 10 genera of Gram-negative bacteria. $\beta$-Lactamase genes such as bla $_{\mathrm{NDM}-1}(n=22)$, bla OXA-181 $(n=21)$, bla $a_{\mathrm{GES}-1}(n=11)$, bla ${ }_{\mathrm{GES}-9}$ $(n=8)$, bla $a_{\text {OXA-23 }}(n=7)$, bla OXA-51 $(n=9)$ and bla IMP-1 $(n=3)$ were found in 70 isolates (with 10 isolates carrying more than one gene type), in contrast to our earlier study which reported a lower prevalence $(27 \%)$ of bla $a_{\mathrm{NDM}-1}$ and bla $a_{\mathrm{OXA}-181}$ genes among carbapenemresistant isolates. ${ }^{18}$ The coexistence of bla $a_{\mathrm{NDM}-1}$ and bla $a_{\mathrm{OXA}-181}$ in E. coli is a reason for major concern from the healthcare perspective. All the $A$. baumannii isolates $(n=7)$ were found to have either OXA-23 or OXA-181 along with OXA-51 intrinsic $\beta$-lactamase. ${ }^{29}$ Earlier reports from India showed the presence of OXA-23 and OXA-51 in carbapenem-resistant Acinetobacter causing serious healthcare problems. ${ }^{12}$ Enterobacteriaceae carried OXA-48-like genes, which are carbapenem-hydrolysing class $D$ B-lacta-

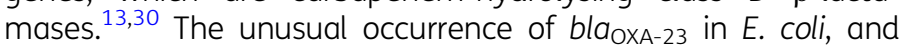
plasmid-encoded bla $a_{\mathrm{OXA}-23}$ and bla $a_{\mathrm{OXA}-51}$ in $\mathrm{K}$. pneumoniae are very important findings of this study, as only very few earlier studies have reported the presence of the bla $a_{\mathrm{OXA}-23}$ gene in E. coli. ${ }^{31,32}$ OXA23-like genes in Enterobacteriaceae may be embedded within a transposon but were not characterized in this study. The resistance reports on E. meningoseptica are very rare in India, ${ }^{31,32}$ and in this study it was found that one isolate of E. meningoseptica was resistant to imipenem and meropenem. Although earlier studies showed the presence of carbapenemase genes in $E$. meningoseptica, in this study no carbapenem resistance genes were found.

Carbapenem resistance among Gram-negative bacteria is becoming very common in Tamil Nadu, India. The isolates producing carbapenemases are mostly MDR and the rapid spread of carbapenem resistance genes is highly concerning. These resistance genes are located adjacent to mobile genetic elements (integrons and transposons), which facilitates the easy transposition between replicons. ${ }^{33}$ The extrachromosomal plasmids are the primary carriers of antibiotic resistance genes and can spread horizontally between strains or species. The recent molecular and genomic surveillance studies are also focused to track the clonally evolving lineages, besides plasmids being the primary focus. ${ }^{34}$ The most common plasmid replicon types for carbapenem resistance genes are IncF, IncA/ $\mathrm{C}_{2}$, IncX3, IncL/M and IncH. ${ }^{35}$ In this study, bla ${ }_{\mathrm{NDM}-1}$ was found in the isolates that carried IncX, IncA/C, IncFIA-FIB and IncFIIA; bla $a_{\mathrm{OXA}-181}$ in IncA/C, IncFIA-FIB and IncFIIA; $b a_{\mathrm{GES}-1 / 9}$ in IncFIA-FIB and IncA/C; bla IMP-1 in IncFIA-FIB; and bla $a_{\mathrm{OXA}-23 / 51}$ in IncA/C. The presence of plasmid-encoded bla $a_{O X A-23 / 51}$ is an important finding, considering the rapid spread of carbapenem resistance among Gram-negative bacteria. Interestingly, the isolates we investigated (such as $P$. aeruginosa, Salmonella Typhi, A. baumannii, S. marcescens, A. xylosoxidans, K. oxytoca, and E. meningoseptica) do not carry any plasmids harbouring 
Table 2. Distribution of resistance genes, plasmid incompatibility grouping and transconjugation studies on Gram-negative isolates that were harbouring resistance genes

\begin{tabular}{|c|c|c|c|c|c|c|}
\hline \multirow[b]{2}{*}{ Isolate } & \multirow[b]{2}{*}{ Source } & \multicolumn{2}{|c|}{ MIC (mg/L) } & \multirow[b]{2}{*}{ Resistance gene } & \multirow{2}{*}{$\begin{array}{l}\text { Plasmid inc/rep } \\
\text { typing }\end{array}$} & \multirow{2}{*}{$\begin{array}{l}\text { Conjugative } \\
\text { plasmid }\end{array}$} \\
\hline & & Meropenem & Imipenem & & & \\
\hline E. coli EC1 & Urine & 16 & 8 & $b l a_{\mathrm{NDM}-1}$ & - & - \\
\hline E. coli EC2 & Urine & 0.25 & 0.12 & ND & - & - \\
\hline E. coli EC3 & Blood & 1 & 1 & ND & - & - \\
\hline E. coli EC4 & Pus & 32 & 32 & $b l a_{\mathrm{NDM}-1}$ & - & - \\
\hline E. coli EC5 & Urine & 8 & 16 & $b l a_{\mathrm{NDM}-1}$ & - & - \\
\hline E. coli EC6 & Pus & 2 & 0.5 & ND & - & - \\
\hline E. coli EC7 & Urine & 8 & 8 & $b l a_{\mathrm{NDM}-1}$ & - & - \\
\hline E. coli EC8 & Urine & 1 & 2 & ND & - & - \\
\hline E. coli EC9 & Urine & 0.25 & 0.5 & ND & - & - \\
\hline E. coli EC10 & Blood & 32 & 8 & $b l a_{\mathrm{NDM}-1}$ & IncX & + \\
\hline E. coli EC11 & Unknown & 0.5 & 0.25 & ND & - & - \\
\hline E. coli EC12 & Urine & 64 & 32 & $b l a_{\mathrm{NDM}-1}$ & - & - \\
\hline E. coli EC13 & Unknown & 0.5 & 1 & ND & - & - \\
\hline E. coli EC14 & Unknown & 2 & 2 & ND & - & - \\
\hline E. coli EC15 & Urine & 32 & 32 & ND & - & - \\
\hline E. coli EC16 & Urine & 0.5 & 1 & ND & - & - \\
\hline E. coli EC17 & Urine & 8 & 4 & $b l a_{\mathrm{NDM}-1}$ & - & - \\
\hline E. coli EC18 & Urine & 0.25 & 0.25 & ND & - & - \\
\hline E. coli EC19 & Unknown & 4 & 4 & ND & - & - \\
\hline E. coli EC2O & Urine & 0.12 & 0.25 & ND & - & - \\
\hline E. coli EC21 & Blood & 16 & 8 & $b l a_{\mathrm{NDM}-1}$ & IncA/C & + \\
\hline E. coli EC22 & Unknown & $>128$ & $>128$ & $b l a_{\mathrm{NDM}-1}$ & - & - \\
\hline E. coli EC23 & Urine & 64 & 8 & $b l a_{\mathrm{NDM}-1}$ & - & - \\
\hline E. coli EC24 & Unknown & 1 & 1 & ND & - & - \\
\hline E. coli EC25 & Urine & $>128$ & 128 & $b l a_{\mathrm{NDM}-1}$ & - & - \\
\hline E. coli EC26 & Urine & 2 & 8 & ND & - & - \\
\hline E. coli EC27 & Urine & 0.25 & 0.5 & ND & - & - \\
\hline E. coli EC28 & Bile fluid & 1 & 1 & ND & - & - \\
\hline E. coli EC29 & Unknown & 8 & 32 & $b l a_{\mathrm{NDM}-1}, b l a_{\mathrm{OXA}-181}$ & IncFIA-FIB & + \\
\hline E. coli EC30 & Urine & 4 & 4 & $b l a_{\mathrm{OXA}-181}$ & - & - \\
\hline E. coli EC31 & Unknown & 16 & 32 & $b l a_{\text {OXA-181 }}$ & - & - \\
\hline E. coli EC32 & Blood & 2 & 2 & ND & - & - \\
\hline E. coli EC33 & Blood & 8 & 8 & $b l a_{\text {OXA-181 }}$ & - & - \\
\hline E. coli EC34 & Bile fluid & 16 & 8 & $b a_{\text {OXA-181 }}$ & - & - \\
\hline E. coli EC35 & Urine & 0.5 & 0.25 & ND & - & - \\
\hline E. coli EC36 & Urine & 32 & 16 & $b a_{\text {OXA-181 }}$ & - & - \\
\hline E. coli EC37 & Bile fluid & 2 & 8 & ND & - & - \\
\hline E. coli EC38 & Urine & 1 & 0.5 & ND & - & - \\
\hline E. coli EC39 & Blood & 64 & $>128$ & $b^{\prime} a_{\text {OXA-181 }}$ & IncFIIA & + \\
\hline E. coli EC40 & Blood & 8 & 8 & $b l a_{\text {OXA-181 }}$ & - & - \\
\hline E. coli EC41 & Blood & 16 & 16 & $b l a_{\mathrm{OXA}-181}$ & - & - \\
\hline E. coli EC42 & Blood & 32 & 16 & $b l a_{\mathrm{IMP}-1}$ & - & - \\
\hline E. coli EC43 & Urine & 0.5 & 1 & ND & - & - \\
\hline E. coli EC44 & Pus & 16 & 64 & $b l a_{\mathrm{GES}-1}$ & IncFIA-FIB & + \\
\hline E. coli EC45 & Unknown & 32 & 32 & $b l a_{\mathrm{GES}-1}$ & - & - \\
\hline E. coli EC46 & Urine & 16 & 8 & $b l a_{\mathrm{GES}-1}$ & - & - \\
\hline E. coli EC47 & Blood & $>128$ & $>128$ & $b l a_{\mathrm{GES}-1}, b l a_{\mathrm{GES}-9}$ & IncFIA-FIB & + \\
\hline E. coli EC48 & Pus & 0.06 & 0.06 & ND & - & - \\
\hline E. coli EC49 & Blood & 64 & 64 & bla $a_{\mathrm{GES}-1}$, bla $a_{\mathrm{GES}-9}$ & - & - \\
\hline E. coli EC50 & Pus & 16 & 32 & bla $_{\mathrm{GES}-1}$, bla $a_{\mathrm{GES}-9}$ & - & - \\
\hline
\end{tabular}

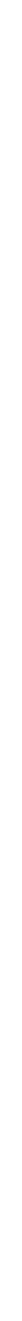


Table 2. Continued

\begin{tabular}{|c|c|c|c|c|c|c|}
\hline \multirow[b]{2}{*}{ Isolate } & \multirow[b]{2}{*}{ Source } & \multicolumn{2}{|c|}{$\mathrm{MIC}(\mathrm{mg} / \mathrm{L})$} & \multirow[b]{2}{*}{ Resistance gene } & \multirow{2}{*}{$\begin{array}{c}\text { Plasmid inc/rep } \\
\text { typing }\end{array}$} & \multirow{2}{*}{$\begin{array}{c}\text { Conjugative } \\
\text { plasmid }\end{array}$} \\
\hline & & Meropenem & Imipenem & & & \\
\hline E. coli EC51 & Bile fluid & 4 & 4 & $b l a_{\mathrm{GES}-9}$ & - & - \\
\hline E. coli EC52 & Unknown & $>128$ & 64 & $b l a_{\mathrm{GES}-9}, b l a_{\mathrm{OXA}-23}$ & - & - \\
\hline E. coli EC53 & Blood & 64 & $>128$ & bla $a_{\mathrm{OXA}-23}$ & - & - \\
\hline E. coli EC54 & Urine & 8 & 8 & $b l a_{\text {OXA-23 }}$ & - & - \\
\hline E. coli EC55 & Unknown & 1 & 0.5 & ND & - & - \\
\hline E. coli EC56 & Urine & 32 & 64 & $b l a_{\mathrm{OXA}-23}$ & - & - \\
\hline E. coli EC57 & Blood & 0.5 & 0.5 & ND & - & - \\
\hline K. pneumoniae KP1 & Urine & 1 & 1 & ND & - & - \\
\hline K. pneumoniae KP2 & Urine & 0.5 & 0.25 & ND & - & - \\
\hline K. pneumoniae KP3 & Blood & $>128$ & 128 & $b a_{\mathrm{NDM}-1}$ & - & - \\
\hline K. pneumoniae KP4 & Bile fluid & 2 & 1 & ND & - & - \\
\hline K. pneumoniae KP5 & Urine & 8 & 32 & ND & - & - \\
\hline K. pneumoniae KP6 & Blood & 0.25 & 0.12 & ND & - & - \\
\hline K. pneumoniae KP7 & Blood & 8 & 16 & $b l a_{N D M-1}$ & - & - \\
\hline K. pneumoniae KP8 & Blood & 0.5 & 0.25 & ND & - & - \\
\hline K. pneumoniae KP9 & Urine & 32 & 32 & $b a_{N D M-1}$ & - & - \\
\hline K. pneumoniae KP10 & Blood & 64 & $>128$ & $b^{\prime a} a_{\mathrm{NDM}-1}$ & IncFIA-FIB & + \\
\hline K. pneumoniae KP11 & Unknown & 8 & 8 & $b l a_{\mathrm{NDM}-1}$ & - & - \\
\hline K. pneumoniae KP12 & Bile fluid & 1 & 1 & ND & - & - \\
\hline K. pneumoniae KP13 & Urine & 32 & 64 & ND & - & - \\
\hline K. pneumoniae KP14 & Urine & 0.06 & 0.12 & ND & - & - \\
\hline K. pneumoniae KP15 & Pulmonary secretion & 8 & 4 & ND & - & - \\
\hline K. pneumoniae KP16 & Urine & 2 & 2 & ND & - & - \\
\hline K. pneumoniae KP17 & Blood & 16 & 16 & $b l a_{\mathrm{OXA}-181}$ & - & - \\
\hline K. pneumoniae KP18 & Unknown & 0.5 & 0.25 & ND & - & - \\
\hline K. pneumoniae KP19 & Blood & 32 & 8 & $b a_{\mathrm{OXA}-181}$ & - & - \\
\hline K. pneumoniae KP20 & Unknown & 128 & 64 & $b l a_{\mathrm{OXA}-181}$ & - & - \\
\hline K. pneumoniae KP21 & Unknown & 8 & 8 & $b a_{\mathrm{OXA}-181}$ & - & - \\
\hline K. pneumoniae KP22 & Unknown & 16 & 2 & ND & - & - \\
\hline K. pneumoniae KP23 & Blood & 16 & 8 & ND & - & - \\
\hline K. pneumoniae KP24 & Blood & 0.25 & 0.25 & ND & - & - \\
\hline K. pneumoniae KP25 & Unknown & 32 & 64 & $b l a_{\mathrm{OXA}-181}$ & - & - \\
\hline K. pneumoniae KP26 & Blood & 8 & 2 & ND & - & - \\
\hline K. pneumoniae KP27 & Unknown & 64 & $>128$ & $b a_{\mathrm{OXA}-181}$ & - & - \\
\hline K. pneumoniae KP28 & Blood & 32 & 8 & $b a_{\mathrm{OXA}-181}$ & - & - \\
\hline K. pneumoniae KP29 & Unknown & 4 & 0.5 & ND & - & - \\
\hline K. pneumoniae KP30 & Urine & 1 & 2 & ND & - & - \\
\hline K. pneumoniae KP31 & Blood & 16 & 4 & $b l a_{\mathrm{GES}-1}$ & IncA/C & - \\
\hline K. pneumoniae KP32 & Unknown & 32 & 32 & $b l a_{\mathrm{GES}-1}$ & - & - \\
\hline K. pneumoniae KP33 & Urine & 128 & $>128$ & $b l a_{\mathrm{GES}-1}$ & - & - \\
\hline K. pneumoniae KP34 & Blood & 8 & 1 & ND & - & - \\
\hline K. pneumoniae KP35 & Unknown & 0.5 & 1 & ND & - & - \\
\hline K. pneumoniae KP36 & Urine & 64 & 16 & $b l a_{\mathrm{GES}-9}$ & - & - \\
\hline K. pneumoniae KP37 & Bile fluid & 64 & 64 & $b l a_{\mathrm{GES}-9}$ & - & - \\
\hline K. pneumoniae KP38 & Blood & 0.5 & 2 & ND & - & - \\
\hline K. pneumoniae KP39 & Urine & $>128$ & $>128$ & $b l a_{\mathrm{OXA}-23}, b l a_{\mathrm{OXA}-51}$ & IncA/C & - \\
\hline K. pneumoniae KP40 & Urine & 32 & 8 & $b l a_{O X A-51}$ & - & - \\
\hline P. aeruginosa PA1 & Pus & 8 & 16 & $b l a_{N D M-1}$ & - & - \\
\hline P. aeruginosa PA2 & Pus & 1 & 0.5 & ND & - & - \\
\hline P. aeruginosa $\mathrm{PA} 3$ & Pus & 16 & 32 & ND & - & - \\
\hline P. aeruginosa PA4 & Bronchial secretion & 0.25 & 0.25 & ND & - & - \\
\hline P. aeruginosa PA5 & Urine & $>128$ & 128 & $b l a_{\mathrm{GES}-1}$ & - & - \\
\hline
\end{tabular}


Table 2. Continued

\begin{tabular}{|c|c|c|c|c|c|c|}
\hline \multirow[b]{2}{*}{ Isolate } & \multirow[b]{2}{*}{ Source } & \multicolumn{2}{|c|}{ MIC (mg/L) } & \multirow[b]{2}{*}{ Resistance gene } & \multirow{2}{*}{$\begin{array}{l}\text { Plasmid inc/rep } \\
\text { typing }\end{array}$} & \multirow{2}{*}{$\begin{array}{l}\text { Conjugative } \\
\text { plasmid }\end{array}$} \\
\hline & & Meropenem & Imipenem & & & \\
\hline P. aeruginosa PA6 & Unknown & 8 & 4 & ND & - & - \\
\hline P. aeruginosa PA7 & Blood & 32 & 32 & $b l a_{\mathrm{GES}-1}$ & - & - \\
\hline P. aeruginosa PA8 & Pus & 64 & 128 & ND & - & - \\
\hline P. aeruginosa PA10 & Pus & $>128$ & 64 & ND & - & - \\
\hline S. Typhi ST1 & Blood & 8 & 64 & ND & - & - \\
\hline S. Typhi ST2 & Unknown & 32 & 32 & ND & - & - \\
\hline S. Typhi ST3 & Urine & 0.5 & 1 & ND & - & - \\
\hline S. Typhi ST4 & Blood & 32 & 64 & ND & - & - \\
\hline S. Typhi ST5 & Urine & 128 & 64 & ND & - & - \\
\hline S. Typhi ST6 & Blood & 16 & 8 & ND & - & - \\
\hline S. Typhi ST7 & Blood & 4 & 4 & ND & - & - \\
\hline S. Typhi ST8 & Unknown & 8 & 32 & ND & - & - \\
\hline E. cloacae EL1 & Urine & 64 & $>128$ & ND & - & - \\
\hline E. cloacae EL2 & Blood & 16 & 8 & $b l a_{\mathrm{NDM}-1}$ & - & - \\
\hline E. cloacae EL3 & Urine & 4 & 64 & $b a_{\mathrm{NDM}-1}$ & IncFIIA & - \\
\hline E. cloacae EL4 & Bronchial secretion & 32 & 128 & ND & - & - \\
\hline E. cloacae EL5 & Blood & 32 & 32 & $b a_{\mathrm{OXA}-181}$ & - & - \\
\hline E. cloacae EL6 & Urine & 16 & 8 & - & - & - \\
\hline E. cloacae EL7 & Urine & 128 & 128 & $b l a_{\mathrm{IMP}-1}$ & - & - \\
\hline E. cloacae EL8 & Urine & 32 & 8 & $b l a_{\mathrm{GES}-9}$ & - & - \\
\hline A. baumannii AB1 & CSF & 8 & 8 & bla $_{\text {OXA-181, }}, b a_{\text {OXA-51 }}$ & - & - \\
\hline A. baumannii AB2 & Urine & 16 & 64 & $b a_{\text {OXA-181 }}, b l a_{\text {OXA }-51}$ & - & - \\
\hline A. baumannii AB3 & Unknown & 0.5 & 1 & $b l a_{\text {OXA }-51}$ & - & - \\
\hline A. baumannii $\mathrm{AB} 4$ & Pus & 8 & 64 & $b l a_{\mathrm{OXA}-23}, b l a_{\mathrm{OXA}-51}$ & - & - \\
\hline A. baumannii AB5 & Blood & 32 & 32 & $b l a_{\text {OXA-23, }}, b l a_{\text {OXA-51 }}$ & - & - \\
\hline A. baumannii AB6 & Urine & 32 & $>128$ & $b l a_{\mathrm{OXA}-51}$ & - & - \\
\hline A. baumannii AB7 & Urine & 16 & 2 & $b l a_{\text {OXA-51 }}$ & - & - \\
\hline S. marcescens SM1 & Bronchial secretion & 8 & 4 & ND & - & - \\
\hline S. marcescens SM2 & Blood & 32 & 64 & $b l a_{\mathrm{NDM}-1}$ & - & - \\
\hline S. marcescens SM3 & Unknown & 128 & 64 & ND & - & - \\
\hline S. marcescens SM4 & Urine & 2 & 2 & ND & - & - \\
\hline S. marcescens SM5 & Unknown & 32 & 8 & ND & - & - \\
\hline A. xylosoxidans AY1 & Unknown & 4 & 8 & ND & - & - \\
\hline A. xylosoxidans AY2 & Blood & 128 & 128 & ND & - & - \\
\hline A. xylosoxidans AY3 & Urine & 32 & 32 & ND & - & - \\
\hline A. xylosoxidans AY 4 & Urine & 1 & 0.5 & ND & - & - \\
\hline A. xylosoxidans AY5 & Urine & 64 & 128 & $b l a_{\mathrm{NDM}-1}$ & - & - \\
\hline K. oxytoca KO1 & Blood & 32 & 128 & ND & - & - \\
\hline K. oxytoca KO2 & Urine & 8 & 16 & ND & - & - \\
\hline K. oxytoca KO3 & Blood & 32 & 32 & ND & - & - \\
\hline K. oxytoca KO4 & Blood & 128 & 128 & bla ${ }_{\mathrm{OXA}-181}$ & - & - \\
\hline K. oxytoca KO5 & Urine & 8 & 2 & ND & - & - \\
\hline P. mirabilis PM1 & Unknown & 1 & 2 & ND & - & - \\
\hline P. mirabilis PM2 & Blood & 128 & 128 & $b a_{\mathrm{OXA}-181}$ & - & - \\
\hline P. mirabilis PM3 & Urine & 8 & 8 & ND & - & - \\
\hline P. mirabilis PM4 & Blood & 0.06 & 0.25 & ND & - & - \\
\hline P. mirabilis PM5 & Urine & 64 & 32 & $b l a_{\mathrm{IMP}-1}$ & IncFIA-FIB & - \\
\hline E. meningoseptica EM1 & CSF & 64 & 64 & ND & - & - \\
\hline
\end{tabular}

ND, not detected; '-' denotes absence; '+' denotes conjugation positive; bold text indicates the isolates were carrying resistance genes on conjugative plasmids. The resistance breakpoint (CLSI) for both meropenem and imipenem is MIC $\geq 4 \mathrm{mg} / \mathrm{L}$. 
resistance genes. This clearly showed that the $\beta$-lactamase or carbapenemase genes were confined to certain strains and present in the different replicon types (plasmids) in the study region. Earlier, the $b a_{N D M}$ IncFII plasmids were reported from India, ${ }^{35}$ and IncFIA-FIB plasmids carrying carbapenem resistance genes such as bla $a_{\text {NDM }}$ were described in samples collected from river and sewage treatment plants in India. ${ }^{7,35}$ This study also showed that some isolates with plasmids were carrying more than one resistance gene, an alarming public health threat. Conjugative plasmids are known to spread their resistance among the bacteria of the same or of different genera. This study showed that all the six E. coli isolates carrying plasmid-encoded resistance genes (bla $a_{\mathrm{NDM}}$ 1, bla $a_{\mathrm{OXA}-181}, b a_{\mathrm{GES}-1}$, and $\left.b / a_{\mathrm{GES}-9}\right)$ were conjugative and one K. pneumoniae plasmid (IncFIA-FIB with bla $a_{\mathrm{NDM}-1}$ ) was transferable, illustrating how resistance genes rapidly spread in clinically relevant bacteria.

We acknowledge several limitations of our study. First, the clinical samples or isolates were collected randomly from the diagnostic centre, which receives clinical samples from multiple hospitals (both in-and out-patient) in the study region. Second, the presence of insertion sequence (IS) elements was not studied. Finally, the transfer of resistance genes between the bacteria was studied using simple conjugation experiments but we did not confirm the results using Southern hybridization or sequencing techniques.

\section{Conclusions}

The increasing frequency of antibiotic resistance in bacteria is a major healthcare problem. This study highlights the distribution of carbapenem-resistant isolates in the region we studied, with the emphasis on the existence of $b l a_{\mathrm{NDM}-1}, b a_{\mathrm{OXA}-181}$, bla $_{\mathrm{IMP}-1}, \mathrm{bla} a_{\mathrm{GES}-1}$, bla $_{\text {GES-9, }}, b_{a_{\text {OXA-23-like, }} \text {, and bla }}$ OXA-51-like among the clinical pathogens. The unusual presence of an E. coli strain carrying bla OXA-23, $_{\text {, }}$ and $K$. pneumoniae isolates carrying bla $a_{\mathrm{OXA}-23}$ and bla $a_{\mathrm{OXA}-51}$ require targeted antibiotic resistance surveillance programmes. The development of alternative therapeutic options should be undertaken immediately to be able to combat the problem of resistance, especially to treat carbapenem-resistant infections in the future. Our study shows that conjugative plasmids are a major contributor to the transfer of resistance in pathogens leading to further dissemination of resistance genes. A One-Health approach is necessary to combat the problem of resistance both at the local and international level.

\section{Acknowledgements}

We thank Vellore Institute of Technology (VIT) for providing partial funding as 'VIT Seed Grant' and Council of Scientific and Industrial Research (CSIR) for providing financial assistance to P.M. in the form of senior research fellowship (SRF) to support this research work. A preprint of this article has been published in BioRxiv and Research Square (Manohar et al.).

\section{Funding}

This study was supported by internal funding.

\section{Transparency declarations}

None to declare. All the datasets are presented in the main manuscript. The raw datasets used and/or analysed during the current study are available from the corresponding author on reasonable request.

\section{Author contributions}

Authors P.M. and R.N. collected the isolates from the clinical samples. Authors P.M. and R.N. undertook the laboratory work, R.N. and B.S.L. interpreted the data, and P.M. and R.N. wrote the initial manuscript. Authors S.L., R.N. and B.S.L. revised and finalized manuscript. All the authors read and approved the manuscript.

\section{Supplementary data}

Tables S1 to S7 are available as Supplementary data at JAC Online.

\section{References}

1 Roca I, Akova M, Baquero F et al. The global threat of antimicrobial resistance: science for intervention. New Microbes New Infect 2015; 6: 22-9.

2 WHO. WHO publishes list of bacteria for which new antibiotics are urgently needed. 2017. http://www.who.int/mediacentre/news/releases/2017/bac teria-antibiotics-needed/en/.

3 Ventola CL. The antibiotic resistance crisis: part 1: causes and threats. PT 2015; 40: 277.

4 McKenna M. Antibiotic resistance: the last resort. Nat News 2013; 499: 394. 5 Ben-David D, Kordevani R, Keller $\mathrm{N}$ et al. Outcome of carbapenem resistant Klebsiella pneumoniae bloodstream infections. Clin Microbiol Infect 2012; 18: 54-60.

$6 \mathrm{Xu} \mathrm{Y,} \mathrm{Gu} \mathrm{B,} \mathrm{Huang} \mathrm{M} \mathrm{et} \mathrm{al.} \mathrm{Epidemiology} \mathrm{of} \mathrm{carbapenem} \mathrm{resistant}$ Enterobacteriaceae (CRE) during 2000-2012 in Asia. J Thorac Dis 2015; 7: 376-85.

7 Akiba M, Sekizuka T, Yamashita A et al. Distribution and relationships of antimicrobial resistance determinants among extended-spectrumcephalosporin-resistant or carbapenem-resistant Escherichia coli isolates from rivers and sewage treatment plants in India. Antimicrob Agents Chemother 2016; 60: 2972-80.

8 Chandran SP, Sarkar S, Diwan V et al. Detection of virulence genes in ESBL producing, quinolone resistant commensal Escherichia coli from rural Indian children. J Infect Dev Ctries 2017; 11: 387-92.

9 Manohar P, Shanthini T, Marathe N et al. Genetic characteristics of plasmid-mediated extended-spectrum $\beta$-lactamases (CTX-M) and its coexistence with carbapenemases (NDM-1) in clinical Gram negative bacteria. Ind J Biotechnol 2017; 16: 189-94.

10 Scaife W, Young HK, Paton RH et al. Transferable imipenem-resistance in Acinetobacter species from a clinical source. J Antimicrob Chemother 1995; 36: 585-6.

11 Teixeira AB, Martins AF, Barin J et al. First report of carbapenem-resistant Acinetobacter nosocomialis isolates harboring ISAba1-bla OXA-23 genes in Latin America. J Clin Microbiol 2013; 51: 2739-41.

12 La MV, Jureen R, Lin RT et al. Unusual detection of an Acinetobacter class D carbapenemase gene, bla OXA-23, in a clinical Escherichia coli isolate. J Clin Microbiol 2014; 52: 3822-3.

13 Paul D, Ingti B, Bhattacharjee $D$ et al. An unusual occurrence of plasmidmediated blaOXA-23 carbapenemase in clinical isolates of Escherichia coli from India. Int J Antimicrob Agents 2017; 49: 642-5.

14 Österblad M, Karah N, Halkilahti J et al. Rare detection of the Acinetobacter class $D$ carbapenemase blaOXA-23 gene in Proteus mirabilis. Antimicrob Agents Chemother 2016; 60: 3243-5.

15 Brown S, Young HK, Amyes SGB. Characterisation of OXA-51, a novel class D carbapenemase found in genetically unrelated clinical strains of Acinetobacter baumannii from Argentina. Clin Microbiol Infect 2005; 11: $15-23$.

16 Chen TL, Lee YT, Kuo SC et al. Emergence and distribution of plasmids bearing the blaOXA-51-like gene with an upstream ISAba1 in carbapenem- 
resistant Acinetobacter baumannii isolates in Taiwan. Antimicrob Agents Chemother 2010; 54: 4575-81.

17 Nachimuthu R, Subramani R, Maray $S$ et al. Characterization of carbapenem-resistant Gram-negative bacteria from Tamil Nadu. J Chemother 2016; 28: 371-4.

18 Manohar P, Shanthini T, Ayyanar R et al. The distribution of carbapenemand colistin-resistance in Gram-negative bacteria from the Tamil Nadu region in India. J Med Microbiol 2017; 66: 874-83.

19 CLSI. Performance Standards for Antimicrobial Susceptibility TestingTwenty-Sixth Edition: M100. 2017.

20 Gheorghe I, Czobor I, Chifiriuc MC et al. Molecular screening of carbapenemase-producing Gram-negative strains in Romanian intensive care units during a one year survey. J Med Microbiol 2014; 63: 1303-10.

21 Dallenne C, Da Costa A, Decré D et al. Development of a set of multiplex PCR assays for the detection of genes encoding important $\beta$-lactamases in Enterobacteriaceae. J Antimicrob Chemother 2010; 65: 490-5.

22 Woodford N, Ellington MJ, Coelho JM et al. Multiplex PCR for genes encoding prevalent OXA carbapenemases in Acinetobacter spp. Int J Antimicrob Agents 2006; 27: 351-3.

23 Lin L, Ling BD, Li XZ. Distribution of the multidrug efflux pump genes, ade $A B C$, adeDE and adeIJK, and class 1 integron genes in multipleantimicrobial-resistant clinical isolates of Acinetobacter baumanniiAcinetobacter calcoaceticus complex. Int J Antimicrob Agents 2009; 33: 27-32.

24 Carattoli A, Bertini A, Villa L et al. Identification of plasmids by PCR-based replicon typing. J Microbiol Methods 2005; 63: 219-28.

25 Oberoi L, Singh N, Sharma Pet al. ESBL, MBL and AmpC $\beta$ lactamases producing superbugs-Havoc in the Intensive Care Units of Punjab India. $J$ Clin Diagn Res 2013; 7: 70.
26 Azim A, Dwivedi M, Rao PB et al. Epidemiology of bacterial colonization at intensive care unit admission with emphasis on extended-spectrum $\beta$-lactamase-and metallo- $\beta$-lactamase-producing Gram-negative bacteria-an Indian experience. J Med Microbiol 2010; 59: 955-60.

27 Nordmann P, Naas T, Poirel L. Global spread of carbapenemase producing Enterobacteriaceae. Emerg Infect Dis 2011; 17: 1791-8.

28 Khurana S, Mathur P, Kapil A et al. Molecular epidemiology of $\beta$-lactamase producing nosocomial Gram-negative pathogens from North and South Indian hospitals. J Med Microbiol 2017; 66: 999-1004.

29 Durante-Mangoni E, Zarrilli R. Global spread of drug-resistant Acinetobacter baumannii: molecular epidemiology and management of antimicrobial resistance. Future Microbiol 2011; 6: 407-22.

30 Bali NK, Fomda BA, Bashir $\mathrm{H}$ et al. Emergence of carbapenem-resistant Acinetobacter in a temperate north Indian State. Br J Biomed Sci 2013; 70: 156-60.

31 Shinha T, Ahuja R. Bacteremia due to Elizabethkingia meningoseptica. IDCases 2015; 2: 13-5.

32 Bhat KS, Priya R, Krishnan L et al. Elizabethkingia meningoseptica bacteremia in a neonate: A case report and mini-review of the literature. J Curr Res SciMed 2016; 2: 42.

33 Partridge SR, Iredell JR. Genetic contexts of blaNDM-1. Antimicrob Agents Chemother 2012; 56: 6065-7.

34 David S, Cohen V, Reuter S et al.; ESCMID Study Group for Epidemiological Markers (ESGEM). Integrated chromosomal and plasmid sequence analyses reveal diverse modes of carbapenemase gene spread among Klebsiella pneumoniae. Proc Natl Acad Sci Usa 2020; 117: 25043-54.

35 Sugawara Y, Akeda Y, Sakamoto $N$ et al. Genetic characterization of blaNDM-harboring plasmids in carbapenem-resistant Escherichia coli from Myanmar. PLoS One 2017; 12: e0184720. 